\title{
PERAN MAJLIS TA'LIM NURUL IMAN DALAM PEMBENTUKAN SIKAP KEAGAMAAN MASYARAKAT DI RT 10/02 KELURAHAN PAGAR DEWA KEC SELEBAR BENGKULU
}

\author{
Maryam \\ IAIN Bengkulu \\ maryam@gmail.com
}

\begin{abstract}
This study aims to examine the role of the majelis ta "lim in developing human qualities in society. Taklim Assembly is regulated in Article 26 paragraph 4 of RI Law Number 20 of 2003 concerning the National Education System. This study uses a qualitative approach with triangulation analysis. The results of this study found that the existence of the Ta'lim Assembly in the era of globalization is very important and one of the most important strongholds in counteracting the negative effects of globalization itself. besides that it also functions as a fostering and developing Islamic religion, a park of spiritual recreation, an arena of silaturrahmi, a means of continuous dialogue between ulama, umaroh and the people and as a medium to convey the idea of modernization that is beneficial for the development of the people.
\end{abstract}

Keywords: Majlis Ta'lim, Attitudes, Society, Religion.

\begin{abstract}
Abstrak. Studi ini bertujuan mengkaji peran majelis ta'lim dalam membanguan kualitas manusia di masyarakat. Majelis Taklim diatur dalam Pasal 26 ayat 4 Undang- undang RI Nomor 20 Tahun 2003 tentang Sistem Pendidikan Nasional. Penelitian ini menggunakan pendekatan kualitatif dengan analisa triangulasi. Hasil penelitian ini menemukan bahwa Keberadaan Majelis Ta'lim dalam era globalisasi sangat penting dan salah satu benteng terpenting dalam menangkal dampak negatif dari globalisasi itu sendiri. selain itu juga berfungsi sebagai membina dan mengembangkan agama Islam, taman rekreasi rohani, ajang silaturrahmi, sarana dialog berkesinambungan antara ulama, umaroh dan umat dan sebagai media penyampai gagasan modernisasi yang bermanfaat bagi pembangunan umat.
\end{abstract}

Kata Kunci: Majelis Ta’lim, Sikap, Masyarakat, Keagamaan.

\section{Pendahuluan}

Majlis Ta'lim berasal dari dua suku kata, yaitu kata Majlis dan kata Ta'lim. Dalam bahasa Arab kata Majlis adalah bentuk isim makan (kata tempat) kata kerja dari Jalasa yang artinya tempat duduk, tempat sidang Kata Ta'lim 
dalam bahasa Arab merupakan masdar dari kata kerja (Allama, Yu 'allimu, Ta'liman) yang mempunyai arti "pengajaran". Dalam Kamus Bahasa Indonesia pengertian Majlis adalah "pertemuan atau perkumpulan orang banyak atau bangunan tempat orang berkumpul. ${ }^{2}$

Dari pengertian tentang Majlis Ta'lim di atas dapatlah dikatakan bahwa Majlis adalah tempat duduk melaksanakan pengajaran atau pengajian agama Islam. Dalam Al-Qu'an Allah berfirman pada surat Al-Mujadalah ayat 11:

Artinya: "Hai orang-orang beriman apabila kamu dikatakan kepadamu: Berlapang-lapanglah dalam majlis', Maka lapangkanlah niscaya Allah akan memberi kelapangan untukmu. dan apabila dikatakan: "Berdirilah kamu", Maka berdirilah, niscaya Allah akan meninggikan orang-orang yang beriman di antaramu dan orang-orang yang diberi ilmu pengetabuan beberapa derajat. dan Allah Maha mengetabui apa yang kamu kerjakan.”

Dari penjelasan tentang pengertian majlis ta'lim diatas, bahwasannya majelis taklim jika kita melihat lapangan, ia bersifat nonformal, namun walaupun demikian fungsi dari majelis taklim itu sendiri sangatlah dirasa dalam masyarakat. Majelis taklim juga banyak disorot karena perannya dalam mengembangkan pribadi Islami pada pesertanya.

Tujuan majelis taklim, rumusannya bermacam-macam. Sebab para pendiri majelis taklim dengan organisasi lingkungan, dan jamaah yang berbeda, tidak pernah menjelaskan secara luas tujuannya. Maka Dra. Hj. Tutty Alawiyah AS, dalam bukunya "Strategi Dakwah di Lingkungan Majelis Taklim", merumuskan tujuan dari segi fungsinya, yaitu:

Pertama, berfungsi sebagai tempat belajar, maka tujuan majelis taklim adalah menambah ilmu dan keyakinan agama, yang akan mendorong pengalaman ajaran agama. Kedua, berfungsi sebagai tempat kontak social, maka tujuannya silaturahmi. Ketiga, berfungsi mewujudkan minat social maka tujuannya meningkatkan kesadaran dan kesejahteraan rumah tangga dan lingkungan jamaahnya. ${ }^{3}$

Dari penjelasan diatas dapat terliat dan dipahami, bahwasannya tujuan majelis taklim sangat erat kaitannya dengan fungsinya. Bahkan tidak hanya Tutty Alawiyah yang merumuskan hal tersebut, Muhsin MK pun dalam bukunya tidak memisahkan antara tujuan dan fungsi majelis taklim. Paparnya dalam bukunya yang berjudul "Manajemen Majelis Takilm"apabila dilihat dari makna dan sejarah berdirinya majelis taklim dalam masyarakat, bisa diketahui dan dimungkinkan lembaga dakwah ini berfungsi dan bertujuan sebagai berikut:
a. Tempat belajar-mengajar
b. Lembaga pendidikan dan keterampilan
c. Wadah berkegiatan dan berkreativitas
d. Pusat pembinaan dan pengembangan

\footnotetext{
${ }^{1}$ Ahmad Waeson Munawir,1997: 202)

${ }^{2}$ Wjs Poerwadaminto,1985 : 99)

3 Tuti Alawiyah : 1997:78)
} 
e. Jaringan komunikasi, ukhuwah dan silaturahim

Majelis taklim juga diharapkan menjadi jaringan komunikasi, ukhuwah, dan silaturahim antarsesama kaum perempuan, antara lain dalam membangun masyarakat dan tatanan kehidupan yang Islami.

Jika kita perhatikan dengan teliti, penjelasan Muhsin MK di atas mengkhususkan majelis taklim yang pesertanya adalah dari kaum wanita. Tapi tidak menutup kemungkinan bahwa kaum lelaki pun dapat mengadakan majelis taklim. Hanya saja di Jakarta dan sekitarnya mungkin lebih banyak dikenal majelis taklim yang banyak dari kaum wanita pesertanya.

Menurut Tuti Alawiyah Tujuan majlis Ta'lim tergantung dari fungsinya yaitu: pertama, sebagai tempat belajar, maka tujuan Majlis Ta'lim adalah menambah ilmu dan keyakinan agama yang akan mendorong pengalaman ajaran agama. Kedua, sebagai kontak sosial maka tujuannya adalah silaturahmi. Ketiga, mewujudkan minat sosial, maka tujuannya adalah meningkatkan kesadaran dan kesejahteraan rumah tangga dan lingkungan jama'ahnya. ${ }^{4}$

Adapun H. M. Arifin menjelaskan bahwa Tujuan Majlis Ta'lim adalah mengokohkan landasan hidup manusia Indonesia pada khususnya di bidang mental spiritual Keberagamaan Islam dalam rangka meningkatkan kualitas hidupnya secara integral, lahiriyah dan batiniyahnya, duniawiyah dan ukhrawiyah secara bersamaan sesuai tuntutan ajaran agama Islam yaitu iman dan takwa yang melandasi kehidupan duniawi dalam segala bidang kegiatannya. Fungsi demikian sejalan dengan pembangunan nasional kita. ${ }^{5}$

\section{Peranan Majlis Ta'lim}

Apabila dilihat dari struktur organisasinya Majlis Ta'lim termasuk organisasi pendidikan luar sekolah yaitu lembaga pendidikan yang sifatnya non formal, karena tidak di dukung oleh seperangkat aturan akademik kurikulum de jure, lama waktu belajar, tidak ada kenaikan kelas, buku raport, ijazah dan sebagainya sebagaimana lembaga pendidikan formal yaitu sekolah. ${ }^{6}$

Disamping peranannya yang ikut menentukan dalam membangkitkan sikap patriotisme dan nasionalisme sebagai modal mencapai kemerdekaan Indonesia, lembaga ini ikut serta menunjang tercapainya tujuan pendidikan nasional. Dilihat dari bentuk dan sifat pendidikannya, lembaga-lembaga pendidikan Islam tersebut ada yang berbentuk langgar, suarau.

Dapat dijelaskan bahwa Majlis Ta'lim adalah lembaga pendidikan non formal Islam. Dengan demikian ia bukan lembaga pendidikan formal Islam seperti madrasah, sekolah, pondok pesantren atau perguruan tinggi. Ia juga bukan organisasi massa atau organisasi politik. Namun, Majlis Ta'lim mempunyai kedudukan tersendiri di tengah-tengah masyarakat yaitu antara lain: a. Sebagai wadah untuk membina dan mengembangkan kehidupan beragama

\footnotetext{
${ }^{4}$ Tuti Alawiyah, :78)

${ }^{5}$ HM Arifin $\left.1995: 120\right)$

${ }^{6}$ H.Nurul Huda 1986/1987 :13)
} 
dalam rangka membentuk masyarakat yang bertakwa kepada Allah SW'T. b. Aman rekreasi rohaniah, karena penyelenggaraannya bersifat santai. c. Wadah silaturahmi yang menghidup suburkan syiar Islam. d. Media penyampaian gagasan-gagasan yang bermanfaat bagi pembangunan umat dan bangsa.

Dalam kaitan ini H.M. Arifin mengatakan: Jadi peranan secara fungsional Majlis Ta'lim adalah mengokohkan landasan hidup manusia muslim Indonesia pada khususnya di bidang mental spiritual keberagamaan Islam dalam upaya meningkatkan kualitas hidupnya secara integral, lahiriah dan batiniahnya, duniawi dan ukhrawiah bersamaan (simultan), sesuai tuntunan ajaran agama Islam yaitu iman dan taqwa yang melandasi kehidupan duniawi dalam segala bidang kegiatannya. Fungsi demikian sejalan dengan pembangunan nasional kita. $^{7}$

Adapun untuk memaksimalkan peran dan fungsi majelis taklim yang perlu dilakukan adalah:

Pertama, memperkuat fungsi majelis taklim sebagai tempat pengajaran agama Islam secara luas, yang meliputi pengkajian tentang pokok-pokok ajaran Islam dan kaitannya dengan persoalan sehari-hari yang dihadapi oleh umat Islam itu sendiri.

Pengetahuan pokok ajaran Islam seperti akidah, syariah akhlak, tafsir, hadits dan tarikh sudah semestinya dintegrasikan dengan sisi kehidupan nyata yang selalu muncul dalam keseharian umat. Hal ini diniscayakan sesuai dengan sumber pokok ajaran Islam, yaitu Al-Qur'an dan As-Sunah yang menyajikan banyak hal yang bisa dipelajari oleh setiap muslim dalam mengikuti suri teladan yang dicontohkan oleh Nabi Muhammad SAW sebagai pembawa Syariat Islam.

Kaitan Islam dengan ilmu-ilmu terapan yang berhubungan langsung dengan nafas kehidupan manusia dirumuskan dalam beberapa pokok bahasan menyangkut hubungan Islam dengan lingkungan, kesehatan, kesenian, politik dan psikologi. Selain mengajarkan tentang ibadah transendental dalam arti hubungan vertikal antara manusia dengan Allah Swt, tapi juga mencakup bagaimana seharusnya seorang muslim menjalin hubungan horisontal dengan sesama manusia dan lingkungannya.

Kedua, meningkatkan fungsi majelis taklim dari tempat penyelenggaraan pengajian menjadi wahana melakukan kaderisasi umat Islam. Kaderisasi adalah suatu system menyiapkan generasi yang akan datang. Sistem ini dikemas dan diakltualisasikan dengan sungguh di majelis taklim. Setiap majelis taklim, sesuai dengan tujuan, misi dan visinya harus melakukan pengkaderan di kalangan jamaahnya. Dengan demikian keberlangsungan majelis taklim akan terus berlanjut.

Ketiga, mengembangkan fungsi konseling. Sebagai salah satu lembaga pendidikan non formal, majelis taklim bertanggung jawab untuk mendidik dan membantu jamaahnya untuk dapat beradaptasi dengan lingkungan masyarakatnya dan mampu memecahkan berbagai persoalan hidup yang

\footnotetext{
${ }^{7}$ HM Arifin,1995:120).
} 
dihadapinya. Melalui kegiatan ta'lim muta'alim (belajar mengajar) yang dikemas sedemikian rupa diharapkan dapat membantu jamaah yang mengalami persoalan-persoalan kehidupan, baik pribadi maupun sosial. Dalam situasi seperti inilah peran dan fungsi konseling akan terasa diperlukan oleh berbagai pihak yang terlibat di majelis taklim, terutama para jamaahnya.

Keempat, menjadikan majelis taklim sebagai pusat pengembangan keterampilan atau skill jamaah. Setiap muslim idealnya bisa berperan ganda dalam kehidupannya, yaitu sebagai 'abid (penyembah Allah) dan sekaligus sebagai khalifah fil ardh (orang yang memakmurkan bumi). Sebagai penyembah Allah SWT, seorang muslim mesti ikhlas menjadikan hidupnya sebagai media pengabdian diri kepada-Nya. Dan sebagai pemakmur di muka bumi, setiap muslim harus berperan dalam mencegah dan memperbaiki kerusakan-kerusakan yang terjadi disekelilingnya.

Dalam konteks inilah majelis taklim bisa menjadi pusat pengembangan keterampilan / skill bagi jamaahnya. Keterampilan yang dimaksud sesuai dengan aneka ragam bakat yang dimiliki oleh setiap individu dalam majelis taklim tersebut. Keterampilan yang dapat dikembangkan meliputi: keterampilan dasar (basic skills) yakni membaca, menulis, berbicara dan lain sebagainya; keterampilan hidup sehari-hari (daily living skills) yang berfungsi untuk melakukan aktifitas untuk memenuhi kebutuhan sehari-harinya; keterampilan personal/ sosial (personal/ social skills); keterampilan mental (mental skills); keterampilan pekerjaan (occupational skills); dan keterampilan atau kecerdasan spiritual (spiritual quotient, SQ).

Kelima, meningkatkan peran pemberdayaan masyarakat melalui pengembangan potensi ekonomi dan sosial. Sebagai tempat berkumpulnya jamaah, majelis taklim diharapkan bisa menjadi media sosial dalam mengkomunikasikan upaya-upaya pembangunan umat, baik secara lahir maupun batin. Melalui majelis taklim yang merupakan sarana efektif dalam interaksi sosial dapat disampaikan informasi yang dapat menggugah jamaahnya untuk berfikir dan melakukan langkah-langkah produktif dalam rangka pemberdayaan ekonomi dan sosial jamaah. Pemberdayaan ekonomi dapat berwujud dukungan dana, baik yang bersifat mandiri maupun menjalin kerjasama dengan donator, baik pemerintah maupun swasta.

Keenam, menjadikan majelis taklim sebagai wadah silaturrahmi dan rekreasi ruhani. Majelis taklim tidak hanya berfungsi sebagai tempat belajar agama Islam, namun juga mampu member warna bagi jamaahnya dalam pembinaan solidaritas sosial yang kuat antar umat Islam melalui silaturrahim. Selain itu juga, majelis taklim bisa memberikan ruang yang cukup lapang dalam menjalankan fungsi rekreasi ruhani melalui nasehat-nasehat dan pesan-pesan moral yang diajarkannya. Dalam situasi dan kondisi itulah, melalui majelis taklim akan tertanam harmoni sosial yang dapat dipetik oleh semua jamaah yang kemudian mengkondisikan suatu jalinan kebersamaan sebagai hamba-hamba Allah yang sama-sama mempunyai hajat mengisi ruang hati dengan siramansiraman dakwah Islamiyah. 
Ketujuh, mengembangkan fungsi sebagai pusat komunikasi dan informasi. Melalui pengembangan fungsi ini diharapkan jamaah akan selalu mendapatkan informasi yang up to date mengenai perkembangan sosial budaya yang terjadi disekitarnya maupun perkembangan dunia yang terjadi dengan sangat cepat. Sebagai pusat informasi, majelis taklim melalui pengurusnya mampu untuk mengumpulkan, menyimpan, memproses dan menyaring berita, data, opini dan komentar secara jelas serta memberikan petunjuk dan arahan bagaimana seharusnya jamaah menyikapi semua hal-hal yang terjadi.

Kedelapan, mengembangkan peran sebagai tempat berkembangnya budaya Islam. Sebagai institusi pendidikan nonformal majelis taklim dapat menciptakan budayanya sendiri, misalnya budaya dalam berpakaian dan perhiasan yang tentunya mencerminkan bagaimana seharusnya jamaah atau masyarakat yang terlibat didalamnya untuk selalu membiasakan tata cara berpakaian yang sesuai dengan ajaran Islam. Begitu pula dalam hal budaya makanan, minuman dan kebiasaan-kebiasaan lainnya.

Kesembilan, menjadikan majelis taklim sebagai lembaga kontrol sosial (social controb). Dengan fungsi control ini. Eksistensi majelis taklim akan semakin diperlukan di tengah-tengah masyarakat. Majelis taklim berperan besar dalam transfer pengetahuan dari pengajar (mualim) kepada jamaahnya dan sekaligus berperan besar dalam memecahkan problematika sosial keagamaan yang dihadapi umat. Seperti misalnya dalam hal mengantisipasi aliran-aliran sesat, pendangkalan akidah, kemaksiatan dan prilaku asosial lainnya yang selalu muncul dan mengancam sendi-sendi kehidupan umat manusia, khususnya umat Islam. Disinilah majelis taklim akan tampil efektif sebagai agen kontrol sosial melalui berbagai peranan dan fungsi yang dijalankannya. ${ }^{8}$

Majlis taklim sebagai lembaga dakwah Islamiyah yangtentunya di dalam pelaksanaan dakwahnya itu memerlukan berbagai bahan dan persiapan yang cukup layak sebagai wasilahdan dapat mengantarkan umat kepada tujuannya. Mengingat Islam adalah dakwah, maka sudah menjadi kewajiban kaum muslimin untuk mempersiapkan segala kelengkapan yang diperlukan bagi kesempurnaan pelaksanaannya berupa perlengkapan atau sarana. Wasail

sarana bentuk jamak dari wasilah artinya mencapai sesuatu dengan kemauan. Sedangkan wasilah dalam gambaran umum adalah segalasesuatu yang denganberangkatnya suatu pekerjaan untuk dilaksanakan atau dibantu merealisasikannya serta menghadapinya sebagaimana mestinya.

Di bidang pendidikan dan pengajaran, wasilah merupakan mediauntuk menyampaikan materi pengajaran kepada anak didik, lebih berbentukmateriil maupun immaterial, teori maupun praktek, dan media ini pun beragam bentuknya. Untuk menyampaikan ajaran kepada umatnya, seorang juru dakwah (dai) dapat menggunakan saranaatau media. Salah satu unsur darikeberhasilan dalam berdakwah adalah kepandaian seseorang dalam memilihdan menggunakan sarana atau media yang ada.

\footnotetext{
${ }^{8}$ Depag RI 2009
} 

berikut:

Adapun sarana pada majlis taklim umumnya ada 4 macam, yaitu Sebagai

a. Organisasi yang riil dan kompak.

b. Prestasi ilmiah yang memadai.

c. Akhlaqul karimah.

d. Kekuasaan dalam masyarakat.

Dari keterangan di atas menunjukkan bahwa sarana sangat menentukan tercapainya tujuan majlistaklim. Penggunaan sarana itu haruslah Sesuaidengan bentuk kegiatan yang diselenggarakan.

4. Organisasi dalam majlis taklim

Kamus administrasi memberikan definisi "organisasi", yaitu suatu sistem usaha kerja sama dari sekelompok orang untukmencapai tujuanbersama. Jadi, organisasi adalah sebuah perangkat untuk mencapai sasaran sasaran tertentu. ${ }^{9}$

Oleh karena itu, organisasi terdiri dari dua orang atau lebih yang bekerja sama untuk mencapai suatu tujuan tertentu.

Kerja sama tersebut sudah barang tentu didorong oleh kehendak atau motif untuk mencapai Tujuan yang telah disepakati.

Mejlis taklim dipandang sebagai salah satu organisasi dakwahIslamiyah mempunyai organisasi yang terdiri dari dai atau muballigh (pihakyang menyampaikan sarana),mad'u(pihak penerima seruan). Penyediaansarana dan fasilitas melalui pembagian fungsi dan tugas kesemuanya berkehendak bekerja sama untuk menampilkan pesan dakwah kearahTercapainya tujuan berupaaktualisasi isi pesan dakwah.Organisasi majlis taklim menurut organisasij ama'ahNya ada beberapa klasifikasi antar lain:

a. Majlis taklim yang dibuka, dipimpin, dan bertempatkhusus yang dibuat oleh pengurus sendiri atau guru.

b. Majlis taklim didirikan, dikelola, dan ditempati bersama, mereka mempunyai pengurus yang dapat diganti menurut periode kepengurusannya (dipemukiman atau dikantor).

c. Majlis taklim mempunyai organisasi induk,seperti Aisyiah,Muslimat,al Hidayah,dan sebagainya.

Klasifikasi organisasi majlis taklim menunjukkan mutu, materi, dan kegiatan tambahan dari majlis taklim sendiri yang masing masing memiliki misi dan visi sesuai dengan tujuan diadakannya majlis taklim ini.

Adapun Materi yang sangat sering dipelajari dalam Majlis Ta'lim yaitu pembacaan, Al-Qur'an serta tajwidnya, tafsir bersama ulum Al-Qur'an, hadits dan Fiqih serta ushul fiqh, tauhid, akhlak ditambah lagi dengan materi-materi yang dibutuhkan para jamaah misalnya masalah penanggulangan kenakalan anak, masalah keluarga, maslah kesehatan dan lain lain

\footnotetext{
${ }^{9}$ Moh E Ayub 1996;91
} 
Materi yang disampaikan dalam Majlis Ta'lim adalah :

a. Kelompok Pengetahuan Agama adalah Bidang pengajaran kelompok ini meliputi tauhid, tafsir, Fiqih, hadits, akhlak, tarikh, dan bahasa Arab.

b. Kelompok Pengetahuan Umum dianataranya tema-tema yang disampaikan adalah yang langsung berkaitan dengan kehidupan masyarakat. Kesemuanya itu dikaitkan dengan agama, artinya dalam menyampaikan uraian-uraian tersebut berdasarkan dalildalil agama baik berupa ayat-ayat Al-Qur'an atau hadits-hadits atau contoh-contoh dari kehidupan Rasulullah SAW.

Penambahan dan pengembangan materi dapat saja terjadi di Majlis Ta'lim melihat semakin majunya zaman dan semakin kompleks permasalahan yang perlu penanganan yang tepat. Wujud program yang tepat dan aktual sesuai dengan kebutuhan jamaah itu sendiri merupakan suatu langkah yang baik agar Majlis Ta'lim tidak terkesan kolot dan terbelakang. Majlis Ta'lim adalah salah satu struktur kegiatan dakwah yang berperan penting dalam mencerdaskan umat, maka selain pelaksanaannya dilaksanakan secara teratur dan periodik juga harus mampu membawa jamaah ke arah yang lebih baik lagi.

Metode adalah cara, dalam hal ini cara penyajian bahan pengajaran dalam Majlis Ta'lim untuk mencapai tujuan yang telah ditetapkan. Makin baik metode yang dipilih makin efektif pencapaian tujuan. Metode mengajar banyak sekali macamnya. Namun bagi Majlis Ta'lim tidak semua metode itu dapat dipakai. Ada metode mengajar di kelas yang tidak dapat pakai alam Majlis Ta'lim. Hal ini disebabkan karena perbedaan kondisi dan situasi antara sekolah dengan Majlis Ta'lim.

Ada berbagai metode yang digunakan di Majlis Ta'lim, yaitu :

a. Metode Ceramah, yang dimaksud adalah penerangan dengan penuturan lisan oleh guru terhadap peserta.

b. Metode Tanya Jawab, metode ini membuat peserta lebih aktif. Keaktifan dirangsang melalui pertanyaan yang disajikan.

c. Metode Latihan, metode ini sifatnya melatih untuk menimbulkan keterampilan dan ketangkasan.

d. Metode Diskusi, metode ini akan dipakai harus ada terlebih dahulu masalah atau pertanyaan yang jawabannya dapat didiskusikan.

Metode penyajian Majlis Ta'lim dapat dikategorikan menjadi:

a. Metode Ceramah, terdiri dari ceramah umum, yakni pengajar/ustadz/kiai tindak aktif memberikan pengajaran sementara jamaah pasif dan ceramahkhusus, yaitu pengajar dan jamaah sama-sama aktif dalam bentuk diskusi.

b. Metode Halaqah, yaitu pengajar membacakan kitab tertentu, sementara jamaah mendengarkan. 
c. Metode Campuran, yakni melaksanakan berbagai metode sesuai dengan kebutuhann. ${ }^{10}$

Pada saat ini metode ceramah sudah membudaya, seolah-olah hanya metode itu saja yang dipakai dalam Majlis Ta'lim. Dalam rangka pengembangan dan peningkatan mutu Majlis Ta'lim dapat digunakan metode yang lain,

\section{Sikap Keagamaan}

\section{Pengertian Sikap}

Sikap adalah merupakan reaksi atau proses seseorang yang masih tertutup terhadap suatu stimulus atau obyek. Sikap tidak dapat dilihat langsung tetapi hanya dapat di tafsirkan terlebih dahulu dari perilaku yang tertutup. Sikap secara nyata menunjukkan konotasi adanya kesesuaian reaksi terhadap stimulus tertentu. Dalam kehidupan sehari-hari adalah merupakan reaksi yang bersifat emosional terhadap stimulus sosial. ${ }^{11}$

Newcomb dalam Notoatmodjo (1993), menyatakan bahwa definisi sikap itu merupakan kesiapan atau kesediaan seseorang untuk bertindak. Sikap itu masih merupakan reaksi tertutup, bukan merupakan reaksi terbuka atau tingkah laku yang terbuka. Dan sikap merupakan kesiapan untuk bereaksi terhadap obyek. Seperti halnya pengetahuan sikap ini terdiri dari berbagai tingkatan, yakni:

\section{a. Menerima (receiving)}

Menerima diartikan bahwa orang (subyek) mau dan memperhatikan stimulus yang diberikan (obyek). Misalnya sikap orang terhadap gizi dapat dilihat dari kesediaan dan perhatian orang itu terhadap informasi-informasi tentang gizi.

\section{b. Merespon (responding)}

Memberikan jawaban apabila ditanya, mengerjakan dan menyelesaikan tugas yang diberikan adalah suatu indikasi dari sikap. Karena dengan suatu usaha untuk menjawab pertanyaan atau mengerjakan tugas yang diberikan, terlepas dari tugas tersebut benar atau salah adalah berarti bahwa orang tersebut menerima ide tersebut.

\section{c. Menghargai (valuing)}

Mengajak orang lain untuk mengerjakan atau mendiskusikan suatu masalah adalah suatu indikasi sikap tingkat tiga. Misalnya seorang ibu yang mengajak ibu yang lain pergi ke Puskesmas untuk menggunakan alat kontrasepsi, ini adalah suatu bukti bahwa si ibu tersebut telah mempunyai sikap positif terhadap alat kontrasepsi.

Menurut Sarnoff (dalam Sarwono, 2000) mengidentifikasikan sikap sebagai kesediaan untuk bereaksi (disposition to react) secara positif (favorably) atau secara negatif (unfavorably) terhadap obyek - obyek tertentu. D.Krech dan R.S

\footnotetext{
${ }^{10}$ Dewan Redaksi Ensiklopedi, 1999:121)

${ }^{11}$ Notoatmodjo, 1993)
} 
Crutchfield (dalam Sears, 1999) berpendapat bahwa sikap sebagai organisasi yang bersifat menetap dari proses motivasional, emosional, perseptual, dan kognitif mengenai aspek dunia individu.

Sedangkan La Pierre (dalam Azwar, 2003) memberikan definisi sikap sebagai suatu pola perilaku, tendensi atau kesiapan antisipatif, predisposisi untuk menyesuaikan diri dalam situasi sosial, atau secara sederhana, sikap adalah respon terhadap stimuli sosial yang telah terkondisikan. Lebih lanjut Soetarno (1994) memberikan definisi sikap adalah pandangan atau perasaan yang disertai kecenderungan untuk bertindak terhadap obyek tertentu. Sikap senantiasa diarahkan kepada sesuatu artinya tidak ada sikap tanpa obyek. Sikap diarahkan kepada benda-benda, orang, peritiwa, pandangan, lembaga, norma dan lain-lain.

2. Ciri-ciri sikap

Sikap memiliki ciri-ciri sebagai berikut : a. Sikap tidak dibawa sejak lahir. Berarti manusia dilahirkan tidak membawa sikap tertentu pada suatu objek. Oleh karenanya maka sikap terbentuk selama perkembangan individu yang bersangkutan. Karena terbentuk selama perkembangan maka sikap dapat berubah, dapat dibentuk dan dipelajari. Namun kecenderungannya sikap bersifat tetap. b. Sikap selalu berhubungan dengan objek. Sikap terbentuk karena hubungan dengan objek-objek tertentu, melalui persepsi terhadap objek tersebut. c. Sikap dapat tertuju pada satu objek dan sekumpulan objek Bila seseorang memiliki sikap negatif pada satu orang maaka ia akan menunjukkan sikap yang negatif pada kelompok orang tersebut. d. Sikap itu dapat berlangsung lama atau sebentarjika sikap sudah menjadi nilai dalam kehidupan seseorang maka akan berlangsung lama bertahan, tetapi jika sikap belum mendalam dalam diri seseorang maka sikap relaatif dapat berubah. e. Sikap mengandung perasaan atau motivasiSikap terhaadap sesuaatu akan diikuti oleh perasaan tertentu baik positif maupun negatif. Sikap juga mengandung motivasi atau daya dorong untuk berperilaku.

Menurut Sarlito Wirawan menjelaskan bahwa ciri-ciri sikap sebagai berikut: Dalam sikap selalu terdapat hubungan subjek-objek, tidak ada sikap tanpa objek. Objek dapat berupa benda, orang, kelompok orang, nilai-nilai sosial, pandangan hidup, hukum, lembaga masyarakat dan sebagainya. Sikap tidak dibawa sejak lahir melainkan dipelajari dan dibentuk daripengalaman. Karena sikap dapat dipelajari, maka sikap dapat berubah-ubah sesuai dengan keadaan lingkungan di sekitar individu yang bersangkutan pada saat yang berbeda-beda. Dalam sikap terdapat juga faktor motivasi dan perasaan. Sikap tidak menghilang walaupun kebutuhan sudah terpenuhi. Sikap tidak hanya satu macam saja, melainkan bermacam-macam sesuai dengan banyaknya objek yang dapat menjadi perhatian orang yang bersangkutan. ${ }^{12}$

\footnotetext{
12Sarwono Wirawan 2000 :95)
} 
Secara bahasa,sikap adalah "Perbuatan dan sebagainya yang berdasarkan pada pendirian, pendapat atau keyakinan"13 Sikap atau dalam bahasa Inggris disebut attitude menurut Ngalim purwanto adalah Perbuatan atau tingkah laku sebagai respon atau reaksi terhadap suatu rangsangan atau stimulus". ${ }^{14}$

Adapun menurutG.W.Allport bahwa "sikap adalah keadaan mental dan syaraf dari kesiapan, yang diatur melalui pengalaman yang memberikan pengaruh dinamik atau terarah terhadap respon individu pada semua objek dan situasi yang berkaitan dengannya. ${ }^{15}$ Dari penjelasan diatas bahwa sikap adalah merupakan kesiapan merespon yang sifatnya positif atau negatif terhadap obyek atau situasi secara konsisten. Apabila individu memiliki sikap yang positif terhadap obyek ia akan siap membantu, memperhatikan,berbuat sesuatu yang menguntungkan obyek itu. Sebaliknya bila ia memiliki sikap yang negatif terhadap suatu obyek, maka ia akan mengecam, mencela, menyerang bahkan membinasakan obyek itu.

Dari beberapa pengertian tentnag sikap dapat disimpulakn bahwa sikap senantiasa diarahkan kepada suatu objek. Artinya tidak ada sikap tanpa objek, sesuai dengan pendapat Sarlito wirawan Sarwono yang memberikan pengertian sikap bahwa "sikap adalah kesiapan pada seseorang untuk bertindak secara tertentu terhadap hal tertentu Adapun objek-objek sikap dapat terarah terhadap benda-benda, manusia, peristiwa-peristiwa, pemandangan-pemandangan, lembaga-lemabaga, norma-norma, nilai-nilai dan sebagainya.

4. Faktor-faktor yang mempengaruhi sikap

Adapun yang mempengaruhi sikap memiliki beberapa factor yaitu :

a. Faktor Intern; yaitu faktor yang terdapat dalam diri orang yang bersangkutan seperti selektifitas, tidak dapat menangkap seluruh rangsangan dari luar melalui persepsi kita oleh karena itu kita harus memilih stimulusstimulus mana yang akan kita dapati dan mana yang harus kita jauhi.

\section{b. Faktor Ekstern:}

1. Sifat objek yang dijadikan sasaran sikap

2. Kewibawaan orang yang mengemukakan suatu sikap

3. Sifat orang-orang atau kelompok yang mendukung sikap tersebut

4. Media komunikasi yang digunakan dalam menyampaikan sikap

Situasi pada saat sikap itu dibentuk tentunya tidak semua factor harus dipenuhi untuk membentuk suatu sikap kadang-kadang satu atau dua faktor sudah cukup. Tetapi makin banyak faktor yang ikut mempengaruhi semakin cepat terbentuknya sikap. ${ }^{16}$

\footnotetext{
${ }^{13}$ Poerwadarminta, 1976: 499),

${ }^{14}$ Ngalim Purwanto, $\left.1995: 141\right)$

${ }^{15}$ Michael Adryanto, 1994.: 137).

16 Isbandi Rukminto,1994:182).
} 


\section{Hasil dan Pembahasan}

Secara geografis Kelurahan Pagar Dewa terletak di antara Pulau Baai dan Bandara fatmawati. Kelurahan pagar Dewa merupakan salah satu kelurahan yang terletak di kecamatan Selebar Kota Bengkulu. berikut:

Adapun batas batas wilayah kelurahan Pagar Dewa adalah sebagai

a. Sebelah utara berbatasan dengan kelurahan Cempaka Permai

b. Sebelah Timur berbatasan dengan kelurahan Sumur Dewa

c. Sebelah barat berbatasan dengan Kelurahan Muara Dua/Kelurahan Bumi Ayu.

d. Sebelah Selatan berbatasan dengan kelurahan Sukarami.

\section{Luas Wilayah Penelitian}

Wilayah Kelurahan pagar Dewa Mempunyai luas $8.73 \mathrm{Km}$, Dengan jumlah RT 50 dan jumlah Rw 08. (BPS 2016)

Penduduk yang berdomisilir di wilayah kelurahan Pagar Dewa terdiri dari penduduk asli dan penduduk pendatang (dari luar Bengkulu). Menurut data statistic kelurahan Pagar Dewa tahun 2015, bahwa penduduk kelurahan Pagar Dewa berjumlah 25.351 Jiwa dan 4.942 KK..

Masyarakat kelurahan Pagar Dewa sebagian besar bermata pencaharian sebagai : Pedagang, Nelayan, petani, peternak dan sebagian lagi sebagai pegawai negeri dan swasta. Akan tetapi ada juga sebagai industry kecil. Hal ini menyebabkan masyarakat pagar Dewa memiliki beragam mata pencaharian sesuai dengan kemampuan dan pekerjaan yang mereka bebani, karena kelurahan pagar Dewa terletak di tengah kota Bengkulu dan dekat dengan pesisir pantai (Pulau Baai).

Pembangunan sarana dan prasarana Dalam meningkatkan pengetahuan dan wawasan ilmu maka di kelurahan pagar Dewa sangat baik dan memiliki beberapa tempat pendidikan diantaranya dari tingkat sekolah TK/Paud sampai dengan perguruan tinggi. Kondisi social Kultural dari kehidupan Beragama

Dilihat dari aspek budaya masyarakat Kelurahan pagar Dewa antara penduduk asli (warga setempatyand sudah lama menetap) dengan pendatang, nampaknya belum terjadi pembauran budaya. Artinya mereka hidupmengelompok dengan budaya(adat istiadat) mereka masing masing pada umumnya masyarakat pendatang tidak mengikuti budaya masyarakat terutama masyarakat pagar Dewa. Misalnya yang berasal dari Sumatera Utara, Sumatera Selatan dan Sumatera Barat dan sebagian lagi Jawa. Mereka tidak meninggalkan budaya mereka seperti ikatan keluarga Minang, Ikatan Pemuda Aceh dan juga Ikatan keluarga Bengkulu itu sendiri dan lain lain.

Akan tetapi mereka ikut menghadiri acar acara hajatan pernikahan, kematian dan lainnya, mereka bisa hidup butuh orang lain dan tidak selamanya hidup mengelompok tanpa membaur dengan masyarakat laiinnya. 
Penduduk kelurahan pagar Dewa adalah masyarakat agamis yang menjunjung tinggi kebebasan dalam memeluk agama.

\section{Majelis Ta'lim Nurul Iman}

Masyarakat Kelurahan pagar Dewa yang mendiami kelurahna, letak yang strategis memiliki banyak potensi untuk dikembangkan. Masyarakat Pagar Dewa termasuk masyarakat yang tergolong maju diantara kelurahan kelurahan yang lainnya di kecamatan selebar Kota Bengkulu. Simpang pagar Dewa dan pasar Induk tradisionla merupakan tempat yang mendukung perekonomian masyarakat.

Dikelurahan pagar Dewa Rt 10 Rw 02 berdiri sebuah masjid yang bernama masjid Nurul Iman yang di dalam organissai masjid itu terdapat majlis Ta'lim . saat ini antusia masyarakat untuk datang ke masjid tinggi begitu juga pada masyarakat jalan Raden Fatah Pagar Dewa. Rt 10 Rw 02.Masjid Nurul Iman adalah salah satu masjid yang pertama berdiri di di Wilayah Jalan Raden Fatah pagar Dewa yang dibangun sekitar | tahun 1987 atas swadaya masyarakat yang sebagai ketua Badan pengurusan masjid (BKM) Drs Rizkan A Rahman. Dengan pertambahnya penduduk dan letak lokasi Majid Nurul Iman yang tidak begitu luas maka ada pengembangan masjid di wilayah ini, dengan berdiri juga masjid seperti Thariqatil jannah Rt 13 Masjid Attaqwa Rt 08 dan masjid Al Muttaqin di RT.07 begitu juga dengan majlis ta'limnya awalnya di sekitar wilayah pagar Dewa yang penggagasnya adalah Dra $\mathrm{Hj}$ Khairunnisa dan. $\mathrm{Ny}$ Harius Rusli. Majlis ta'lim Nurul Iman Ide dan gagasan mendirikan majlis ta'lim tersebut didasari atas kebutuhan masyarakat terhadap ilmu agama Islam serta pada kondisi bangsa Indonesia yang dianggap mulai meninggalkan tradisi dan nilai-nilai keagamaan serta merosotkan moralitas bangsa akibat pengaruh budaya bangsa barat. Dikarenakan letak masjid Nurul Iman yang tidak memungkinkan untuk dilakukan pengembangan dalam bangunannya karena tanah yang kurang begitu luas dan dengan pertambahan penduduk maka bedirilah masjid masjid lain begitu juga dengan majlis ta'limnya. ${ }^{17}$

Majlis ta'lim Nurul Iman terbentuk sekitar tahun 1990 pada awal berdirinya masih sederhana.dibawah naungan dari Badan kesejahteraan masjid (BKM) dari bidang pendidikan. Pada awalnya jumlah dari majlis ta'lim itu sangat sedikit dan khususnya bagi kalangan dewasa dan orang tua. Dan Seiring dengan perkembangan dan tuntutan masyarakat, maka majlis ta'lim tersebut sudah memiliki jamaah kurang lebih 120 Anggota yang terdiri dari beberapa rt dilingkungan Jalan Raden Fatah Pagar Dewa Kota Bengkulu. ${ }^{18}$

Majlis ta'lim Nurul Iman berdiri di jalan Raden fatah RT. 10 RW. 02 Kelurahan pagar Dewa Kecamatan Selebar kota Bengkulu. Majlis Ta'lim tersebut sekarang masih aktif, dan memiliki keanggotaan yang meningkat.

\footnotetext{
${ }^{17}$ Wawanvara Drs H Rizkan Rahman 22 Juli 2016).

18 wawancara Dra Hj Khairunnisa 04 Juli 2016
} 
Menurut salah seorang pengurus majlis ta'lin Nurul Iman mengatakan, bahwa peningkatan anggota dikarenakan majlis ta'lim tersebut kegiatannya dilaksanakan setiap minggu setiap hari jum'at dan penuh dengan aktivitasaktivitasnya yang selalu berkembang pesat sesuai dengan kebutuhan masyarakat. ${ }^{19}$

Seperti hal organasasi lain yang memiliki struktur organisasi yang jelas, maka majlis ta'lim Nurul Iman di Jalan raden fatah kelurahan pagar Dewa Kecamatan Sellebar Kota Bengkulu juga membentuk struktur organisasi secara jelas untuk menunjang pelaksanaan majlis ta'lim tersebut. ${ }^{20}$

Pengurus inilah yang mengelola kegiatan yang ada di Majlis Ta'lim sehingga berbagai kegiatan Keberagamaan berjalan dengan baik. Dalam arti yang lebih luas manajemen yang dipakai di Majlis Ta'lim ini sudah relative profesional, terlihat dari distribusi kerja yang tersebar pada orang-orang yang mempunyai kapabilitas di bidangnya. Kegiatan Majlis Ta'lim Nurul Iman dilaksanakan satu kali seminggu, yaitu hari Jum'at setelah shalat Jum'at. Materi yang dikaji adalah Hadits, Tafsir, Akhlaq, Fiqh, yang diajarkan secara bergiliran oleh para guru dalam satu minggu.

Selain kegiatan pengajian Mingguan, pengajian Perempuan Majlis Ta'lim Nurul Iman juga melaksanakan pengajian bulanan, dengan mengundang para ulama atau kyai untuk memberikan siraman rohani atau pengetahuan agama Islam (ceramah). Pengajian Majlis Ta'lim Nurul Iman juga mempunyai berbagai kegiatan yang dikelola para pengurus untuk memenuhi kebutuhan jama'ah. Kegiatan tersebut antara lain:

Memperingati hari-hari besar Islam yang secara rutin dilaksanakan, yaitu:

Peringatan Maulid Nabi Muhammad SAW, Peringatan Isra Mi'raj Nabi Muhammad SAW, Peringatan Tahun Baru Islam.

Kunjungan ke Majlis Ta'lim-Majlis Ta'lim lain (Study Comperative). Kegiatan ini dilakukan dengan tujuan untuk menambah wawasan para jama'ah dan mempererat tali silaturahim antar sesama muslim.

Kegiatan sosial dengan menjenguk dan memberi santunan kepada anggota yang sakit atau meninggal dunia.

Informan penelitian ini sebanyak 11 orang yang terdiri dari pengurus Badan Kesejahteraan masjid (BKM) Nurul Iman ,Tokoh Masyarakat, Pengurus majlis ta'lim Nrul Iman Dan Anggota majlis ta'lim Nurul Iman:

\footnotetext{
${ }^{19}$ Wawancara dengan Bu Hj Raudhah selaku ketua majlis ta'lim Nurul Iman pada tanggal 23 juli 2016).

${ }^{20}$ Wawancara dengan Upi hidayah selaku pengurus majlis ta'lim Nurul iman pada tanggal 23 juli 2016).
} 


\section{Kondisi, Pengurus, Anggota dan Pengajar}

Salah satu penunjang keberhasilan pelaksanaan majlis ta'limNurul Iman adalah susunan kepengurusan yang baik, sehingga masing-masing memiliki tanggung jawab dan tidak ada tumpang tindih dalam menjalankan tugas. Di samping itu, majlis ta'lim Nurul Iman dibawah naungan Badan kesejahteraan Masjid (BKM) juga diasuh oleh ustadz-ustadz yang memiliki kapabilitas keilmuan yang berbeda-beda sesuai dengan disiplin ilmu yang ditekuni. Ustadz-ustadz yang ikut mengelola majlis ta'lim Nurul Iman seperti ustaz H. Rozian karnedi M.Ag yang mengisi ceramah agama setiap minggu kedua dan ustaz Wira Hadikusuma M.Si pada minggu ke empat juga terkadanng diberikan materi materi yang ada kaitannya dengan kesehatan Ibu dan anak yang pernah diisi oleh Bidan Oci lestari juga masalah fiqih seperti pembahasan tentang waris dan lain sebagainya yang diisi oleh Yusmita M.Ag dan masalah psikologi Oleh asniti karni M.Pd Kons. ${ }^{21}$

Anggota majlis ta'lim Nurul Iman terdiri dari kaum ibu ibu yang muda maupun yang sudah tua yang berjumlah 127 yang aktif berjumlah 70 orang ini disebabkan karena adanya kesibukan masing masing anggota yang rata rata sebagai pegawai negeri yang terkadang tidak dapat hadir dan jugaadanya pengembangan masjid yang awalnya majlis ta'lim berpusat di Nurul Iman akan kemudian berkembang ke masjid lain seperti masjid thariqatul jannah dan Attaqwa (wawancara Upidayah 23 juli 2016)

Untuk menunjang pelaksanaan kegiatan majlis ta'lim Nurul Iman, sarana dan prasarana harus dipenuhi. Hasil wawancara penulis dengan pengurus dengan (Fitriani tanggal 23 Juli 2016) bahwa sarana prasarana apa yang ada di masjid dapat dipakai karena majlis ta'lim Nurul dibawah naungan Badan Kesejahteraan masjid (BKM) pada bidang pendidikan seperti masjid tempat belajar membaca Al-Qur'an,bermusyawarah dan lain sebagainya. Sedangkan untuk adiministrasi seperti lemari untuk menyimpan arsip milik dari majlis ta'lim Nurul Iman dan alat alat rebana

Di Dalam pelaksanaan kegiatan majlis Ta'lim nurul Iman selalu berkoordinasi dengan Badan kesejahteraan masjid BKM karena majlis ta'lim ini dibawah tanggung jawab Badan Kesejahteraan masjid (BKM) yang merupakan bagian dari kegiatan pada bidang pendidikan I ketika akan melakukan kegiatan seperti wisata religi dan lain sebagainya. Selain itu juga selalu malakukan koordinasi dengan majlis ta'lim lainnya seperti menghadiri kegiatan majlis ta'lim Permata dan majlis ta'lim kota yang para anggotanya selalu antuasias dan menginginkan hadir dengan di utus beberapa anggota untuk menhadiri kegiatan di Permata setiap bulannya pada minggu kedua

Setelah Organisasi ini dibentuk, maka disusunlah program kerja sebagai pedoman kegiatan selanjutnya. Adapun program kerja tersebut meliputi:

1. Melaksanakan kegiatan pengajian 1 Minggu Sekali dalam satu bulan

\footnotetext{
${ }^{21}$ Wawancara Hj Raudhah Tobil 23 Juli 2016)
} 
2. Menjalin kerjasama dengan Majlis Ta'lim Permata Pagar Dewa

3. Belajar membaca Al-Qur'an dan mengkaji Isi Al-Qur'an setiap Minggu Pertama

4. Mengundang Ustaz/ustazah 2 Minggu sekali yaitu Minggu kedua dan minggu ke empat

5. Mengundang para ahli di bidang kesehatan

6. Mengundan para ahli psikologi dan konseling

7. Melaksanakan kegiatan acara pada hari besar Islam

8. Melaksanakan kegiatan wisata religi

9. Pada bulan puasa Memberi ta;zil di masjid nurul Iman

10. Pada bulan ramadhan Melakukan tadarussan setiap malam

11. Selalu berkoordinasi dengan pihak Badan Kesejahteraan Masjid (BKM)

12. Berkunjung ke rumah anggota ketika ada musibah

13. Belajar dan berlatih Rebana

Dana yang didapatkan oleh majlis ta'lim Nurul Iman yaitu didapatkan 10\% Badan Kesejahteraan Masjid (BKM) Nurul Imann yang berasal daridari donator dan kotak amal masjid nurul Iman berasal yang di sumbangkan kepada majlis ta'lim, Selain pendanaan yang berasal dari Badan kesejahteraan masjid (BKM). Pendanaan kegiatan majlis Ta'lim itu sendiri bersumber dari pengurus dan anggotanya dengan melaui kotak amal yang yang dijalankan ketika setiaada peretmuan dan kegiatan majlis ta'lim, ini sesuai dengan keikhlasan dari pengurus maupun dari anggota.

Adapun Peranan dari Majelis Ta'lim Nurul Iman secara umum dapat terlihat dari berbagai kegiatan yang telah diselenggarakan. Kegiatan-kegiatan tersebut pada akhimya akan membawa dampak positif bagi jama'ah yang selanjutnya menjadi landasan kehidupan seharihari.

Peranan Majelis Ta'lim Nurul Iman, antara lain:

1.Memberikan wawasan keagamaan yang luas kepada para jama'ah Peran Majelis Ta'lim Nurul Iman dalam pengembangan wawasan keagamaan para jama'ahnya, terlihat dari kegiatan-kegiatan yang dilaksanakan. Dari berbagai kegiatan-kegiatan tersebut secara langsung para jama'ah majelis ta'lim tersebut dapat mengetahui dan memahami lebih mendalam tentang wawasan agama Islam dan akhimya menambah pengetahuan mereka tentang Islam sebagai agama yang mereka yakini serta mereka jadikan sebagai landasan hidup sehari-hari.

2. Mempererat tali silaturrahim antar sesama muslim Dari berbagai kegiatan yang dilaksanakan Majelis Ta'lim Nurul Iman, tidak hanya untuk menambah wawasan keagamaan Islam saja tetapi juga menjadi ajang untuk mempererat tali silaturrahmi sesama jama'ah.

4. Menciptakan masyarakat yang bertaqwa serta memiliki akhlaqul karimah Peran Majelis Ta'lim Nurul Iman dalam menciptakan masyarakat yang bertaqwa serta berakhlaqul karimah, dilakukan dengan cara memberikan pemahaman tentang pentingnya pengamalan agama dalam kehidupan sehari-hari. Hal ini yang akan menjadikan benteng pertahanan untuk menghadapi kemajuan tekhnologi dan perkembangan jaman. 
5. Melahirkan pribadi-pribadi yang bertanggung jawab, baik di lingkungan keluarga, masyarakat, serta bangsa dan negara. Dengan kegiatan-kegiatan dan pemahaman tentang agama yang diberikan di Majelis Ta'lim Nurul Iman diharapkan para jama'ah mampu menerapkan dan mengamalkannya dalam kehidupan sehari-hari, baik di lingkungan keluarga, masyarakat, bangsa dan negara serta menjadi pribadi yang bertanggung jawab di berbagai aspek kehidupan. Iman adalah 22

Kegiatan kegiatan yang telah dilaksanakan oleh majlis ta'lim Nurul

1. Melaksanakan kegiatan pengajian 1 Minggu Sekali dalam satu bulan

Kegiatan pengajian dilaksanakan setiap minggu yaitu setiap hari jum'at dimulai dari jam 14.00 sampai dengan 16.00.dengan kegiatan diisi ceramah pada minggu kedua dan minggu keempat yang penceramahnya telah ditetapkan oleh pengurus. dan pada Minggu pertama dan ketiga diisi dengan belajar mengaji, terkadang juga diisi dengan materi kesehatan terutama kesehatan Ibu dan Anak oleh seorang Bidan dan masalah fiqih oleh ahli Fiqih dengan membahas masalah waris dan lain sebagainya.

2. Menjalin kerjasama dengan Majlis Ta'lim Permata

Dalam meningkatkan kerjasama dengan majlis ta'lim lainnya, maka majlis ta'lim Nurul Iman selalu hadir ketika ada kegiatan majlis Ta'lim Permata yang dilaksanakan satu bulan sekali

3. Belajar membaca Al-Qur'an dan kajian Tafsir setiap Minggu Pertama

Di dalam membaca Al-Qur'an haruslah membacanya dengan baik dan sesuai dengan tajwid maka majlis ta'lim Nurul Iman menjadwalkan pembacaan Al-Qur'an pada minggu pertama dan terkadang mengkaji Isi Al-qur'an beserta tafsirannya yang di isi oleh Ustazah agustini M.Ag.

Dalam meningkatkan pengetahuan agama dan perubahan sikap keagamaan maka pengurus majlis ta'lim nurul Iman mengundang penceeramah Agama yang dilaksanakan pada minggu kedua dan minggu keempat yang penceramahnya telah ditetapkan oleh pengurus yaitu Ustaz H. Rozian Karnedi M.Ag dan ustaz Wira Hadikusuma M.Si.

\section{Aktivitas Tambahan}

a) Mengundang para ahli di bidang kesehatan

Ilmu Kesehatan adalah sangat penting diketahui oleh karena itu Untuk meningkatkan pemahaman anggota terhadap kesehatan baik kesehatan ibu dan anak berdasarkan ajaran Islan maka pada minggu ketiga Pengurus majlis ta'lim Nurul Iman mengundang seorang bidan yang diisi oleh Bidan Oci lestari.

b) Mengundang para ahli psikologi dan konseling

Mendidik anak yang baik berdasarkan ajaran Islam itu sangat penting, maka guna mengetahui hal tersebut maka pengurus majlis T'alim 
mengudang ahli konseling dan psikologi yang diisi oleh Asniti karni ,M.Pd.Kons.

c) Melaksanakan kegiatan acara pada peringatan hari besar Islam

Pada hari besar Islam pengurus majlis ta'lim nurul Iman selalu melaksanakan nya dengan mengundang penceramah seperti hari besar Islam Is'ra' Mi'raj Nabi Muhammad SWA, Maulid Nabi Muhammad SAW, Tahun baru Islam 1 muharram dan selalu melaksanakan halal bihalal.

d) Melaksanakan kegiatan wisata religi

Dalam Rangka pengenalan terhadap alam untuk menunjukkan rasa bersyukur terhadap Allah sang pencipta alam dan juga untuk menghindari kejenuhan para Anggota terhadap kegiatan yang selalu dilakukan di ruang majlis Ta'lim, maka pada bulan Maret tahun 2015 pengurus majlis ta'lim nurul Iman mengadakan wisata religi dengan berkunjung ke objek wisata alam perkebunan teh di gunung Dempo Pagar alam dengan diikuti para anggota dan pengurus Badan Kesejahteraan masjid (BKM) seerta mengundang ustaz untuk memberikan pencerahan.

e) Pada bulan puasa Memberi ta'zil di Masjid Nurul Iman

Untuk menambah keimanan kepada allah dan untuk berbagi kepada sesama yang berpuasa maka Pada Bulan Ramadhan pengurus majlis Ta'lim Nurul Iman menjadwalkan kepada pengurus, anggota dan masyarakat sekitar mesjid untuk memberikan ta'jil berbuka puasa setiap hari sesuai dengan kemampuan.

f) Pada bulan ramadhan Melakukan tadarussan setiap malam

Di Bulan ramadhan adalah bulan yang penuh berkah, sebagai umat Islam dituntut untuk selalu berbuat amal kebajiakan dan dengann banyak membaca Al-Qur'an. Pengurus majlis ta'lim nurul Iman melakukan tadarusan setiap malam sesudah shalat tarawih bahkan sering khatam Al-qur'an 3 sampai 4 kali khatam.

Selalu berkoordinasi dengan pihak Badan Kesejahteraan Masjid (BKM)

Untuk lancarnya program kerja, pengurus majlis ta'lim nurul iman selalu berkoordinasi dengan pengurus Badan Kesejahteraan masjid (BKM) Nurul Iman. Ketika anggota majlis ta'lim mendapatkan musibah maka pengurus dan anggota majlis ta'lim nurul Iman berkunjung ke rumah anggota yang mendapatkan musibah untuk menunjukkan rasa kebersaman dan rasa turut berduka

\section{Kurikulum}

Kuriklum yang digunakan di Majlis Ta'lim Nurul Iman ialah "biden curriculum" ini berarti kurikulum yang digunakan tidak tertuang dan tersusun de jure, akan tetapi bersifat kesepakatan hasil musyawarah anggota.Materi yang diajarkan di Majlis Ta'lim Nurul Iman antara lain: 
- Jum'at pertama: Belajar membaca Al-Qur'an dilanjutkan Siraman Rohani bertemakan Tafsir atau menjelaskan ayat ayat Al-Qur'an Fiqih oleh Ustadzah Agustini M.Ag

- Jum'at kedua: Pengajian Yasiin dan siraman rohani oleh Ustadz H Rozian Karnedi M.Ag dan sebagian Anggota pergi untuk menghadiri kegiatan pengajian di majlis ta'lim Permata Pagar Dewa.

- Jum'at ketiga membaca Yasin dan diisi ceramah dengan tema beraneka ragam seperti tema kesehatan Keluarga,oleh Bidan tema fiqih seperti tentang waris dan tema tentang psikologi

- Jum'at keempat belajar Membaca Al-Qur'an dan siraman rohani bertemkan Tauhid dan lain sebagainya oleh Ustadz Wira Hadikususma M.Si.

Proses pengajian dilaksanakan dari jam 14.00 sampai dengan 16.00

Metode yang digunakan adalah metode internalisasi pembiasaan dengan diawali membaca ayat-ayat Al-Qur'an berjama'ah di pimpin ustadz ustadzah. Selanjutnya metode ceramah, yaitu seorang guru menyampaikan pelajaran di depan para jama'ah dan jama'ah mendengarkan serta menyimak bacaan yang sedang dijelaskan, dan ada tanya jawab

1. Peran Majelis Ta'lim Nurul Iman dalam pembentukan sikap keagamaan para jamaahnya dalam pelaksanaan ibadah dan sosial.

Majlis Ta'lim adalah tempat duduk melaksanakan pengajaran atau pengajian agama Islam yang dilakukan oleh umat Islam baik dikalangan Bapak bapak maupun ibu ibu._Didalam pelaksanaannya majlis Ta'lim terdapat program untuk meningkatkan pemahaman anggotanya terhadap ajaran agama Islam dan perubahan dalam sikap keagamaan dalam meningkatkan ibadah .

Berdasarkan hasil wawancara dan pengamatan penulis dapatkan dari kebanyakan imforman bahwa peran dari majlis ta'lim Nurul Iman dalam membina sikap keagamaan para jamaahnya dalam segi ibadah sangatlah berpengaruh sekali terutama terhadap ibadah yang mereka laksanakan sehari hari misalkan pada awalnya para jamaah atau anggota anti atau enggan untuk datang ke masjid pada akhirnya rajin pergi ke masjid untuk melaksanakan kegiatan baik berupa kegiatan shalat berjamaah terutama shalat lima waktu, membaca Al-Qur'an, di bulan ramadhan setiap malam mengadakan tadarusan, bagaimana cara mendidik anak dengan baik, menjadi istri yang baik sesuai tuntunan agama Islam, mengetahui hukum waris itu dikarenakan adanya pemahaman mereka tentang pentingnya ke masjid berdasarkan ilmu yang mereka dapatkan dari penceramah dan juga pada awalnya para jamaa ah atau anggota belum mengetahui pelaksanaan ibadah madhah ataupu ibadah ghairo madhah maka dengan pergi ke majlis ta'lim mereka dapat mengetahui pentingnya ibadah itu .

Namun ada sebagian dari imforman yang belum begitu sempurna dalam pengetahuan dan pelaksanaan ibadahnya dikarenakan kurang begitu aktif mengikuti kegiatan majlis ta'lim yang dilaksanakan satu minggu sekali setiap hari 
jumat yang dimulai pada jam 14.00. Ini dikarenakan ada beberapa kesibukan seperti bagi PNS dengan diberlakukannya pulang jam kantor pada sore hari maka tidak dapat mengikuti kegiatan secara rutin sehingga tidak banyak yang didapatkan ilmu yang diberikan oleh penceramah.

Dari penjelasan di atas dapat dipahami dan disimpulakn bahwa masyarakat, jama'ah atau anggota khususnya masyarakat yang berada di lingkungan masjid nurul Iman sebagian dari mereka sangat antusias datang ke masjid ta'lim nurul Iman dan selama mereka mengikuti kegiatan tersebut mereka mengalami perubahan dalam sikap keagamaan terutama dalam ibadah ini dibuktikan pada awalnya belum mengetahui apa pentingnya pergi ke masjid, pentingnya belajar membaca Al-Qur'an, pentingnya mendididk anak dengan baik, menjadi istri yang baik sesuai dengan tuntunan agama Islam dan lain sebagainya yang berkaitan dengan ibadah maka dengan datang dan mengikuti kegiatan majlis ta'lim bertambah pengetahuan dan dapat menjalankan ibadah ibadah yang diperintahkan Allah SWT

Menurut mereka pentingnya datang majlis ta'lim nurul Iman dikarenakan para pengurusnya selalu memberikan motivasi kepada anggotanya dan kegiatan yang dilaksanakan sangatlah bervariasi tidak monoton hanya belajar meembaca Al-Qur'an saja atau mendengarkan ceramah akan tetapi ada juga belajar do'a, zikir dan ceramahnya nya temanya selalu bervariasi sehingga dengan kegiatan ini para anggota bersemangat untuk datang ke majlis ta'lim Nurul iman dan apa yang mereka dapatkan dari kegiatan majlis ta'lim ini mereka amalkan dan berdampak terhadap pelaksanaan ibadah mereka dalam kehidupan sehari hari.

Dan sebagian dari masyarakat, jamah atau anggota yang tidak dapat mengikuti kegiatan majlis ta'lim secara rutin, tentunya tidak akan dapat mendapatkan ilmu ilmu yang telah diberikan oleh penceramah.

Adapun Peran majlis Ta'lim Nurul Iman dalam pembentukan sikap keagamaan jama'ah bidang sosial;

Berdasarkan hasil wawancara penulis terhadap beberapa imforman bahwa peran majlis ta'lim Nurul Iman dalam pembentukan sikap keagamaan bidang social sangat baik sekali. Hal ini dibuktikan dengan selama mengikuti kegiatan majlis ta'lim para jama'ah rasa sosialnya sangat tinggi sekali seperti setiap bulan ramadhan secara bergiliran mereka selalu memberikan ta'jil atau buka puasa di masjid Nurul Iman, berkunjung ke rumah anggota ketika mendapatkan musibah, memberikan santunan bila ada musibah, saling membatu ketika ada kegiatan pada masjid Nurul iman.

Dan sebagian imforman menjelaskan dengan mengikuti kegiatan majlis ta'lim banyak sekali manfaat dan ada perubahan dalam sikap mereka terutama dalam bergaul seperti ketika ada yang membicarakan orang lain maka dengan sendirinya mereka menyadari dan ingat apa yang pernah penceramah katakan bahwa itu adalah sesuatu hal yang berdosa besar termasuk ghibah.

Dari penjelasan di atas dapat disimpulkan dan dipahami bahwa peran majlis ta'lim Nurul Iman dalam pembentukan sikap keagamaan terutama dalam 
bidang social dangatlah berpengaruh sekali. Ini terlihat ketika mereka melakukan kegiatan selalu bergotong royon atau bersama sama dan dalam kehidupan sehari hari ada perubahan dalam sikap social ini menunjukkan apa yang telah dilakukan majlis ta'lim Nurul Iman sangat berdampak adanya perubahan dalam sikap social pada masyarakat atau anggota.

2. Materi yang disampaikan pada majlis ta'lim Nurul Iman kelurahan pagar dewa kecamatan selebar Bengkulu.

Untuk menambah wawasan dalam bidang ilmu penegtahuan terutama dalam bidang agama dan untuk memotifasi anggota dapat hadir pada majlis ta'lim itu terletak pada materi yang ditawarkan dan dilaksanakan pada majlis ta'lim nurul Iman. Berdasarkan hasil wawancara dengan pengurus majlis ta'lim Nurul Iman adalah sangat berpariasai tidak hanya monoton dengan membaca al-Qur'an atau ceramah dengan tema agama yang masalah ibadah saja akan tetapi diisi juga dengan tema tema yang sifatnya umum seperti tentang kesehatan dan tentang kehidupan sehari hari.

Dalam penyampaian materi tidak hanya diisi oleh ustaz yang dijadwalkan saja akan tetapi di isi juga oleh para ahli sesuai dengan bidang atau pembahasan materi yang diberikan dan penyampaiannya tidak hanya di dalam majlis saja akan tetapi diluar juga seperti melakukan wisata religi mengunjungi majlis ta'lim yang laiinnya seperti majlis ta'lim Permata Pagar Dewa

b. Analisa tentang peran Majlis Taklim Nurul Iman dalam memebentuk sikap keagamaan dalam Ibadah dan social RT 10/02 Kelurahan Pagar Dewa Kecamatan Selebar bengkulu

Majlis taklim merupakan lembaga pendidikan agama Islam non formal yang merupakan sarana dakwah umat Islam yang bertujuan meningkatkan pengetahuan dan kesadaran beragama di kalangan masyarakat Islam pada umumnya dan khususnya bagi para anggota (jama'ah) untuk meningkatkan amal ibadah masyarakat dan supaya membantu pemerintah dalam mewujudkan masyarakat yang bertaqwa kepada Tuhan Yang Maha Esa dan mensukseskan program pemerintah, terutama pembangunan mental dan spiritual.Begitu pula keberadaan majlis taklim nurul Iman Pagar Dewa Selebar Bengkulu terutama dalam melaksanakan shalat berjamaa'ah.

Shalat berjamaah disyariatkan Islam dalam berbagai kesempatan dengan tujuan berkumpulnya umat Islam untuk saling memupuk rasa persaudaraan, persatuan, bertukar pikiran, dan persamaan. Shalat berjamaah lebih utama daripada shalat sendirian, karena dengan shalat berjamaah pahalanya berlipat 27 derajat. Selain itu, dengan adanya shalat berjamaah masyarakat bisa berkumpul bersama antara fakir dan orang kaya tanpa ada perbedaan dan pemisah diantara keduanya, dengan demikian, akan terjalin ukhuwah Islamiyah.Hendaklah kaum muslim berhati-hati untuk tidak terlewatkan shalat berjama'ah tanpa udzur yang sah, yang bisa kaum muslim pertanggungjawabkan dihadapan Allah SWT, yang mengetahui segala perkara gaib. Tidak mengapa, jika kaum muslim berudzur sesuatu yang memaksa kaum muslim tetap tinggal di rumah, karena dirasakan perkara itu ada baiknya, atau 
mengandung maslahat bagi urusan agama dan dunia. Jika tidak, maka hendaklah kaum muslim tidak melewatkan shalat berjama'ah di masjid pada waktu-waktu shalat yang telah ditentukan. Apabila perlu, ajaklah anggota keluarga, sekalipun hanya seorang saja untuk shalat bersama kaum muslim, agar kaum muslim terlepas dari tanggung jawab dan mendapat pahala pula. Karena, kelebihan pahala berjama'ah itu akan diperoleh dengan shalat seorang imam dan seorang makmum, malah semakin banyak yang makmum semakin banyak pula pahalanya, disebabkan keutamaan shalat berjama'ah itu.Bahwasannya hendaknya kaum muslim berhati-hati untuk tidak terlewatkan shalat berjama'ah tanpa udzur yang sah, yang bisa kaum muslim pertanggungjawabkan dihadapan Allah SWT, yang mengetahui segala perkara gaib. Tidak mengapa, jika kaum muslim berudzur sesuatu yang memaksa kaum muslim tetap tinggal di rumah, karena dirasakan perkara itu ada baiknya, atau mengandung maslahat bagi urusan agamadan dunia. Jika tidak, maka hendaklah kaum muslim tidak melewatkan shalat berjama'ah di masjid pada waktu-waktu shalat yang telah ditentukan. Apabila perlu, ajaklah anggota keluarga, sekalipun hanya seorang saja untuk shalat bersama kaum muslim, agar kaum muslim terlepas dari tanggung jawab dan mendapat pahala pula. Karena, kelebihan pahala berjama'ah itu akan diperoleh dengan shalat seorang imam dan seorang makmum, malah semakin banyak yang makmum semakin banyak pula pahalanya, disebabkan keutamaan shalat berjama'ah itu.Dari data yang diperoleh melalui wawancara dengan Bapak Yohanes selaku Imam masjid Nurul Iman pada tanggal 12 Juni 2016 dan wawancara dengan bapak Rizkan rahman Selaku Ketua BKM pada tanggal 26 Juni 2016 bahwasannya shalat jamaah yang dilaksanakan di masjid Nurul Iman hanya shalat Maghrib, Isya', dan Shubuh. Sedangkan untuk Dzuhur dan Ashar para jamaahnya mempunyai aktivitas-aktivitas sendiri, yaitu memenuhi kebutuhan atau mencarikan nafkah untuk keluarganya. Sedangkan dulu sebelum adanya majlis taklim Nurul Iman itu yang mau melaksanakan shalat berjamaah hanya sekitar kurang lebih satu sampai empat orang saja. Sedsangkan sesudah adanyamajlis taklim itu yang jamaah bertambah kurang lebih 30 orang.

Dengan demikian, perkembangan spiritual pada masyarakat sekitar masjid nurul Iman pagar Dewa selebar bengkulu sudah meningkat menjadi lebih baik dan maju. Hal tersebut dapat dilihat dengan adanya shalat berjamaah yangdilaksanakan setiap hari walaupun hanya shalat Shubuh, Maghrib, dan Isya.

keberadaan majlis taklim Nurul Iman sudah mampu menuangkan pengetahuan dan membangkitkan kesadaran beragama sehingga terwujud masyarakat yang bertaqwa kepada Tuhan Yang Maha Esa. Adapun bentuk-bentuk kegiatan yang ada di majlis taklim Nurul Iman adalah:

1. Pengajian rutin, pengajian rutin majlis taklim Nurul Iman adalah kegiatan yang dilaksanakan setiap Jum'at siang dengan tujuan memperoleh ilmu dan kemampuan khususnya ilmu agama Islam dan para jama'ah bisa mengaplikasikannya dalam kehidupan sehari-hari. 
2. Tadarusan, kegiatan ini bertujuan menambah ilmu dan keyakinan kepada Allah.

3. Peringatan hari besar Islam sepert maulid Nabi dan Isra' mi'raj bertujuan meningkatkan kesadaran dan memahami arti dari hari hari yang sangat bersejarah bagi umat Islam.

4. Melakukan Kunjungan Sosial

5. Melakukan wisata religi

Berdasarkan tujuan kegiatan-kegiatan majlis taklim Nurul Iman sesuai dengan tujuan majlis taklim. Berdasarkan keterangan di atas kegiatan yang diadakan majlis taklim Nurul Iman sesuai dengan teori yang dikemukakan oleh Tutty Alawiyah bahwasannya dari pengalaman selama ini, majlis taklim merupakan tempat berkumpul dan tempat bermasyarakat. Sambil berkumpul,

Waktu yang tersedia diisi dengan bersama membaca ratib dan alQur'an. Para jamaah mendapat pelajaran agama dari seorang atau beberapa orang guru tetap. Dalam kesempatan-kesempatan tertentu, mereka memperingati hari-hari besar Islam. Acara ini biasanya diisi dengan ceramah mubaligh atau mubaligh undangan. Disamping menyerap pendidikan formal seperti itu, majlis-majlis taklim selalu memiliki kegiatan tambahan, khususnya

Mengadakan kunjungan ke majlis ta'lim yang lainnya lawatan muhibbah keluar daerah atau melaksanakan wisata religi

c. Analisa tentang Materi yang Diajarkan dalam Majlis Taklim Nurul Iman di MasjidNurul Iman Pagar Dewa Selebar Bengkulu

Dalam sebuah proses pendidikan, salah satu faktor komponen yang harus ada adalah materi pengajaran. Sebagaimana dalam kegiatan majlis taklim Nurul Iman yang diselenggarakan di masjid nurul Iman pagar Dewa Selebar Bengkulu juga ada beberapa materi yang diberikan.Dengan adanya materi yang disampaikan di majlis taklim tersebut dan ditambah dengan

Adanya muballigh atau pemimpin sebagai petunjuk arah kepada pencerahan hidup bergama yang Islami artinya sebagai tempat pembinaan keagamaan majlis taklim Raudhatul Jannah harus dapat menjadikan jama'ah sebagai jama'ah yang sadar atas tugas sebagai khalifah di muka bumi dan bertanggung jawab atas semua tindakannya di akhirat nanti. Sistem pendekatan keagamaan yang ada di majlis taklim Nurul Iman digunakan agar para jama'ahnya dapar memahami betul ajaran agama Islam sehingga di dalam jiwanya timbul perasaan paham dalam arti mau mengamalkan ajaran tersebut khususnya shalat berjama'ah di masjid.Sebagaimana observasi pada tanggal 10 Juni 2016 dan wawancara dengan Ketua majlis ta'lim Ibu $\mathrm{Hj}$ Raudha tobilpada tanggal 8 Juli 2016 bahwasannya materi yang diajarkan di majlis taklim Nurul Iman adalah membaca shalawat bersama, mengajarkan

Pengetahun dan ketrampilan dasar ajaran agama, berupa tuntutan ibadah shalat. Sedangkan pengetahuan agama yang diajarkan berupa ilmu fiqh, hadits, tafsir, tasawuf, dan tarikh,.Data tersebut sesuai dengan teori Tutty 
Alawiyah yang mengklasifikasikan jenis majlis taklim dari materi yang diajarkan kepada lima hal:

Pertama, majlis taklim yang tidak mengajarkan sesuatu secara rutin.

Kedua, majlis taklim yang mengajarkan pengetahuan dan

ketrampilan dasar ajaran agama, seperti belajar membaca al-Qur'an atau penerangan fiqh.

Ketiga majlis taklim yang mengajarkan pengetahuan agama tentang fiqh tauhid, atau akhlak yang diberikan dalam cerama oleh para muballigh, kadangkadang dilengkapi pula dengan tanya jawab.

Keempat, . majlis taklim dengan ceramah ceramah dan bahan pelajaran pokok yang diberikan teks tertulis, materi pelajaran disesuaikan dengan situasi hangat berdasarkan ajaran Islam.Untuk memudahkan penyusunan materi pelajaran, ajaran Islam dibagi menjadi sejumlah bidang pengajaran seperti tauhid, fiqh, tafsir, hadith, akhlak, tarikh, tentang kesehatan dan lain-lain.

Berdasarkan data yang penulis peroleh dari lapangan, bahwasannya materi yang disampaikan dalam majlis taklim Nurul Iman sejalan dengan pengklasifikasian bagian satu, dua, tiga, dan empat

\section{Penutup}

Berdasarkan hasil penelitian yang telah penulis lakukan peneliti mengambil beberapa kesimpulan sebagai berikut:

1. Kegiatan yang dilaksanakan Majlis Ta'lim Nurul Iman tidak hanya menyelenggarakan pengajian rutin saja. Akan tetapi masih banyak kegiatan lain yang sering diselenggarakan, antara lain:

a. Memperingati hari-hari besar Islam yang secara rutin dilaksanakan, yaitu: Peringatan Maulid Nabi Muhammad SAW, Peringatan Isra Mi'raj Nabi Muhammad SAW, Peringatan Tahun Baru Islam, dan lain sebagainya.

b. Kunjungan ke Majlis Ta'lim-Majlis Ta'lim lain (Study Comperative). Kegiatan ini dilakukan dengan tujuan untuk menambah wawasan para jama'ah dan mempererat tali silaturahim antar sesama muslim.

2. Majlis Ta'lim Nurul Iman sebagai sebuah lembaga pendidikan non-formal banyak mempunyai peranan dalam pembentukan sikap, antara lain: Meningkatkan pengamalan ibadah bagi masyarakat atau anggota seperti ibadah madhah dan ghairu madhah. Menumbukan rasa social yang tinggi. Memberikan wawasan Keberagamaan yang luas. Mempererat tali silaturrahim antar sesama muslim. Menciptakan masyarakat yang bertaqwa serta memiliki akhlaqul karimah. Membentuk pribadi-pribadi yang bertanggung jawab, baik di lingkungan keluarga, masyarakat, serta bangsa dan negara. 


\section{Daftar Pustaka}

Anas Sudijono, Pengantar Statistik Pendidikan, Jakarta: PT. Raja Grafindo Persada, 2005

Bambang Soepeno, Statistik Terapan Dalam Ilmu-Ilmu Sosial Dan Pendidikan, Jakarta: PT. Rineka Cipta, 1997, Cet I.

Bungin, Burhan. (2010). Metode Penelitian Kualitatif (Aktualisasi Metodelogis Kearah Ragam Varian Kontemporer. Jakarta: Rajawali Pers

Dewan Redaksi Ensiklopedi, Ensiklopedi islam, Jakarta,Pt melitian baru Van Hoeve 1999 cet ke 10

Regulasi Majelis Taklim; Pedoman Pembinaan Majelis Taklim” (Depag RI: 2009)

HM Arifin. Kapita Selekta Pendidikan, IslamDan Umum, Bina Karsa 1991

Al-Munawwir, Kamus Al-Munawwir, Yogyakarta, Pustka progresif 19970 cet 14

Ngalim Purwanto, Psikologi Pendidikan, Bandung, remaja Rosda karya 1995 Cet 10

Nurul Huda, Pedoman majlis Ta'lim, Jakarta; Koordinasi,Dakwah Islam 1986.1987

N. Grass, W.S. Massan and A.W.Mc. EachernExploration Role Analisis dalam David Berry, Pokok-Pokok Pikiran Dalam Sosiologi Jakarta: PT. Raja Grafindo Persada, 1995).

Michael Adryanto, Psikologi Sosial (Jakarta, Erlangga, 1994) cet III

Poerwadaminta, Kamus umum bahasa Indonesia, Jakarta balai Pustaka, 1976, Cet I

Soejono Soekanto, Sosiologi suatu pengantar, Jakarta rajawali Press, 1982)

Wirawan Sarwono Sarlito, Dr., Teori-teori Psikologi Sosial, PT. Raja Grafindo Persada Jakarta: 2000, cet. V

Tuti alawiyah, Ilmu Jiwa Agama, Jakarta, Bulan bintang ,2003, Cet XVIYunus Mahmud,Sejarah pendiddikan Islam,Jakarta PT Hidayah karya Agung, 1986

WJS,Poewadarminti, kamus umum bahas Indonesia, Jelita balai Pustaka,1985

Yunus Mahmud,Sejarah pendiddikan Islam, Jakarta PT Hidayah karya Agung, 1986 